\title{
The effect of glucosinolate fraction concentrations in rapeseed meal on daily protein deposition in the body and on internal organ weights of growing pigs
}

\author{
St. Raj, G. Skiba, H. Fandrejewski and D. Weremko
}

The Kielanowski Institute of Animal Physiology and Nutrition, Polish Academy of Sciences

05-llo Jablonna. Poland

\begin{abstract}
Thirty-five gilts weighing $25 \mathrm{~kg}$ were divided into five groups and until reaching $70 \mathrm{~kg}$ fed with isoenergetic diets based on cereals and rapeseed meal differing in the content of glucosinolate fractions. Daily protein deposition in the body, weight of thyroid glands, liver, kidneys, and $T_{3}$ and $T_{4}$ hormone levels in the blood were measured as affected by the concentration of alkenyl- (alk-) and indole- (ind-) glucosinolates (GL).

Daily protein deposition in the body decreased (by $8.5 \%$, statistically nonsignificant), but the weight of internal organs increased (thyroid glands by $210 \%, \mathrm{P}<0.001$; liver by $50 \%, \mathrm{P}<0.01$, and kidneys by $17 \%, \mathrm{P}<0.05$ ) as the alk- and ind-GL concentration in the diets rose (from 0.52 to 2.10 and from 0.17 to 0.40 mmoles $\mathrm{kg}^{-1}$, respectively). The correlation coefficients (partial) indicated that the concentration of ind- had a greater influence on weight of internal organs than alk-GL. Indoleand alkenyl-glucosinolates had a similar effect on the level of $\mathrm{T}_{3}$ and $\mathrm{T}_{4}$ hormones in the blood, but did not influence protein deposition.
\end{abstract}

KEY WORDS: pigs, glucosinolates, protein deposition

\section{INTRODUCTION}

Despite the considerable reduction of the glucosinolates (GL) content in new rape seed cultivars, approximately thirty kinds of glucosinolates are still present in this plant. Only a few of these glucosinolates are significant from the nutritional point of view: progoitrin, gluconapin, glucobrassicanapin, napoleiferin (alk-GL) as well as glucobrassicin and neoglucobrassicin (ind-GL) (Chichłowska, 1990; Muśnicki et al., 1995). The antinutritional effect of alk- and ind-glucosinolates on voluntary feed intake, weight of thyroid gland and internal organs of rats is well 
known (Bille et al., 1983). Data from literature indicate that ind-GL have a much stronger influence on the weight of the thyroid than alk-GL, but both kinds of GL have a similar effect on liver and kidney weight (Thomke et al., 1998). Progoitrin is the major alkenyl-glucosinolate (46-60\%) and its antinutritional effect on performance, organ mass, and nitrogen utilization has been investigated (Bille et al., 1983; Chichłowska, 1990; Thomke et al., 1998). However, we have not found any reports in the literature on the influence of types of glucosinolates in rapeseed meal (RSM) on protein deposition in the body.

The main objective of this study was to test the hypothesis that alkenyl- and indole-glucosinolate concentrations in the diet influence daily protein deposition in growing pigs.

\section{MATERIAL AND METHODS}

Thirty-five gilts were divided into five groups and from 25 to $70 \mathrm{~kg} \mathrm{BW}$ were fed diets based on cereals and rapeseed meal (16 to $32 \%)$. The diets were isocaloric (12.50 $\pm 0.03 \mathrm{MJ} \mathrm{ME})$ and balanced in terms of amino acid content, but differed

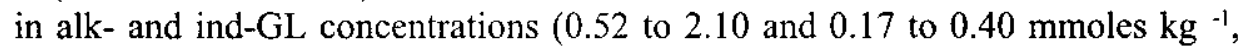
respectively). The RSM came from three batches that differed in alk- and ind-GL content $\left(3.24,4.66\right.$ or 6.56 and $1.06,0.881 .19$ mmoles kg $^{-1}$, for batches A, B and C, respectively).

The animals were kept in individual pens without bedding, fed ad libitum and voluntary feed intake was measured once a week. The internal organs and thyroid gland were weighed at slaughter and samples of blood were taken to determine the concentration of $\mathrm{T}_{3}$ and $\mathrm{T}_{4}$ hormones. Protein deposition in the body was measured by the comparative slaughter technique (Kotarbińska, 1971). The GL of RSM was analyzed by HPLC according to ISO-9167 (1991). Plasma thyroid hormones were assayed in blood samples after slaughter using RIA kits (RIA-T ${ }_{3}$ and RIA-T from $_{4}$ POLATOM, Świerk, Poland).

The statistical significance of differences was evaluated by variance analysis. A relationship between the concentration of alk- and ind-GL and daily protein deposition and the weight of internal organs, thyroid gland, and hormones $T_{3}$ and $\mathrm{T}_{4}$ levels in the serum blood was shown by partial coefficients of correlation using Statgraphics ver. 6.0.

\section{RESULTS}

Metabolizable energy $\left(28.4 \pm 0.02 \mathrm{MJ} \mathrm{d}^{-1}\right)$ and total lysine intake $\left(22.3 \pm 0.41 \mathrm{~g} \mathrm{~d}^{-1}\right)$ were similar for all groups. Daily feed intake (average $2.32 \pm 0.03 \mathrm{~kg}$ ), daily gain 
$(866 \pm 23 \mathrm{~g})$ and feed conversion ratio $\left(2.67 \pm 0.09 \mathrm{~kg} \mathrm{~kg}^{-1}\right)$ were not significantly affected by dietary alk- and ind-GL concentrations. However, the daily gain and feed conversion ratio of pigs fed mixtures containing 32\% RSM (batch C) were lower compared with the average of the remaining four groups $\left(831 \mathrm{~g} \mathrm{~d}^{-1}\right.$ and $2.85 \mathrm{~kg} \mathrm{~kg}^{-1}$ vs $875 \pm 16$ and $2.64 \pm 0.05 \mathrm{~kg} \mathrm{~kg}^{-1}$ ) (Table 1).

TABLE 1

Performance, weight of internal organs and daily protein deposition in the body of growing pig fed diets with different concentration of alkenyl and indole-glucosinolates

\begin{tabular}{lcccccc}
\hline Batches of RSM & $\mathrm{A}$ & $\mathrm{A}$ & $\mathrm{B}$ & $\mathrm{C}$ & $\mathrm{C}$ & \multirow{2}{*}{ SEM } \\
\cline { 2 - 6 } $\mathrm{RSM}, \%$ & 16 & 25 & 25 & 25 & 32 & \\
\hline Alkenyl-GL, mmol kg-1 & 0.52 & 0.85 & 1.17 & 1.64 & 2.10 & 0.56 \\
Indole-GL, mmol kg-1 $^{-1}$ & 0.17 & 0.27 & 0.22 & 0.30 & 0.40 & 0.14
\end{tabular}

Performance

\begin{tabular}{lcccccr} 
average daily gain, $\mathrm{g}$ & 895 & \multicolumn{1}{c}{887} & \multicolumn{1}{c}{858} & \multicolumn{1}{c}{858} & 831 & 22.96 \\
feed intake, $\mathrm{kg} /$ day & 2.34 & 2.28 & 2.31 & 2.32 & 2.37 & 0.03 \\
feed conversion ratio, $\mathrm{kg} / \mathrm{kg}$ & 2.61 & 2.57 & 2.69 & 2.70 & 2.86 & 0.09
\end{tabular}

\begin{tabular}{lcccccc} 
Results after slaughter & & & & & & \\
$\quad$ protein deposition, g/d & 139 & 141 & 134 & 131 & 127 & 5.8 \\
liver, g & $1332^{\mathrm{A}}$ & $1408^{\mathrm{A}}$ & $1719^{\mathrm{B}}$ & $1921^{\mathrm{B}}$ & $1997^{\mathrm{B}}$ & 258 \\
kidneys, g & $294^{\mathrm{a}}$ & $300^{\mathrm{a}}$ & $325^{\mathrm{ab}}$ & $360^{\mathrm{b}}$ & $344^{\mathrm{b}}$ & 34 \\
thyroid glands, g & $5.03^{\wedge}$ & $6.20^{\wedge}$ & $15.2^{\mathrm{B}}$ & $17.3^{\mathrm{B}}$ & $15.6^{\mathrm{B}}$ & 4.9 \\
$\mathrm{~T}_{3}, \mathrm{ng} / \mathrm{ml}$ & - & 1.18 & 1.21 & 0.99 & 0.94 & 0.24 \\
$\mathrm{~T}_{4}, \mathrm{ng} / \mathrm{ml}$ & - & 42.0 & 40.7 & 30.23 & 28.14 & 5.71 \\
\hline
\end{tabular}

${ }_{\mathrm{a}, \mathrm{b}}-\mathrm{P}<0.05 ;{ }^{\mathrm{A} . \mathrm{B}}-\mathrm{P}<0.01$

Daily protein deposition in the body decreased (by $12 \mathrm{~g} \mathrm{~d}^{-1}$, difference insignificant) and weight of internal organs increased (liver by $665 \mathrm{~g}, \mathrm{P}<0.01$; thyroid glands by $10.6 \mathrm{~g}, \mathrm{P}<0.001$, and kidneys by $50 \mathrm{~g}, \mathrm{P}<0.05$ ) as the alk- and ind-GL concentration in the diets rose from 0.52 to 2.21 and from 0.17 to $0.40 \mathrm{mmol} \mathrm{\textrm {kg } ^ { - 1 }}$, respectively.

The effects of the dietary concentration of alk- and ind-GL in the diets on organ weights and daily protein deposition are presented as partial correlation coefficients (data from pigs fed diets with $25 \%$ of RSM, $n=21$ ) (Table 2). These data indicate that the concentration of ind- had a greater effect on the weight of the thyroid glands and liver $(\mathrm{P}<0.01)$ than the alk-GL. A similar tendency was observed for kidneys weight $(P=0.12)$. The alk- and ind-glucosinolates decreased $T_{3}$ and $\mathrm{T}_{4}$ levels $(\mathrm{P}<0.05)$ in the serum, but did not significantly change the rate of protein deposition. 
TABLE 2

Correlation coefficients (partial) for protein deposition, weight of internal organs, level of hormones $\mathrm{T}_{3}$ and $\mathrm{T}_{4}$ in the blood in relation to dietary concentration of alk- and ind-Gl (data from pigs fed diets containing $25 \%$ of $\mathrm{RSM}, \mathrm{n}=21$ )

\begin{tabular}{lcccccc}
\hline & $\begin{array}{c}\text { Protein } \\
\text { deposition }\end{array}$ & $\begin{array}{c}\text { Thyroid } \\
\text { glands, }\end{array}$ & $\begin{array}{c}\mathrm{T}_{3} \\
\mathrm{ng} / \mathrm{ml}\end{array}$ & $\begin{array}{c}\mathrm{T}_{4} \\
\mathrm{ng} / \mathrm{ml}\end{array}$ & $\begin{array}{c}\text { Liver } \\
\mathrm{g}\end{array}$ & $\begin{array}{c}\text { Kidneys } \\
\mathrm{g}\end{array}$ \\
\hline Ind-GL & -0.19 & $0.55^{* *}$ & $-0.39^{*}$ & $-0.55^{*}$ & $0.47^{* *}$ & 0.14 \\
Alk-GL & 0.10 & $0.33^{*}$ & $-0.41^{*}$ & $-0.55^{*}$ & -0.12 & 0.01 \\
\hline
\end{tabular}

$* \mathrm{P}<0.05 ; * * \mathrm{P}<0.01$

\section{DISCUSSION}

The contents of alk- and ind-GL (from 73.4 to $82.4 \%$ and from 14.9 to $24.0 \%$, respectively) in the batches of RSM used in this study were similar to those in Polish varieties (Muśnicki et al., 1995). Usually, an increase in the alk-GL content takes place when the total concentration of GL in RSM rises, which has a negative effect on pig performance (Tomke et al., 1998). In our investigation, the pigs fed the diet with the highest RSM content grew slowly and had a worse feed conversion ratio then other pigs. This was probably due to the increase in both alk- and ind-GL concentrations in the diet. Tomke at al. (1998) reported a similar effect.

The daily protein deposition in the body of pigs fed on mixtures with the highest concentration of alk-GL agreed with the results presented in an earlier study (Bille et al., 1983) that showed a negative effect of increased alk-GL content on daily gain and nitrogen utilization. Additionally, increasing the level of alk-GL in the RSM increased the toxic effect of degradation products on the weight of internal organs, which is expressed as enlargement of the liver, kidneys and thyroid gland and reduction of serum $\mathrm{T}_{3}$ and $\mathrm{T}_{4}$ levels (Boltshauser et al., 1993).

\section{CONCLUSIONS}

Both alk- and ind-glucosinolates have a negative effect on the weight of internal organs and thyroid hormones, however, the effect of the ind-GL concentration in the diet is much stronger than that of alk-GL. The thyroid gland is the most sensitive to increasing the concentration of ind-glucosinolates.

Increasing the concentration of alk- and ind-GL in the diet for growing pigs had no significant effect on protein deposition in the body. 


\section{REFERENCES}

Bille N., Eggum B.O., Jacobsen I., Olsen O., Sørensen H., 1983. Antinutritional and toxic effects in rats of individual glucosinolates ( \pm myrosinases) added to a standard diet. 1 . The effect of protein utilisation and organ weights. Z. Ticrphysiol. Ticrernäbr. Futtermittelk. 49, 195-210

Boltshauser M., Stoll P., Gutzwiller A., 1993. Dietary thiosulfate fails to counteract the effects of 00rapeseed on the thyroid gland, the liver and the kidneys of growing pigs. J. Anim. Physiol. Anim. Nutr. 70, 173-179

Chichlowska J., 1990. Effect of antimetabolic factors from post extraction rapeseed meals on selected hormones and physiological indices in rats and swine (in Polish). Rocz. AR Poznań. Rozpr. Nauk. No. 205, 1-47

ISO-9167-1, Polish Standard (in Polish), 1991. HPLC Method of Glucosinolates Determination

Kotarbinska M., 1971.The chemical composition of the body in growing pigs. Rocz. Nauk rol., B-93, 129-135

Muśnicki Cz., Mroczyk W., Potkański A., 1995. Chemical composition of the seeds of native and foreign winter rape cultivars (protein, carbohydrates, glucosinolates) (in Polish). Rośliny Oleiste. XVI, 105-112

Thomke S., Pettersson H., Neil M., Håkansson J., 1998. Skeletal muscle goitrin concentration and organ weights in growing pigs fed diets containing rapeseed meal. Anim. Feed Sci. Tech. 73, $207-215$

\section{STRESZCZENIE}

Wplyw koncentracji frakcji glukozynolanów w śrucie rzepaku 00 na odłożenie bialka w ciele oraz masę narządów wewnętrznych rosnących świń

Trzydzieści pięć loszek o masie ciała $25 \mathrm{~kg}$ podzielono na 5 grup i żywiono do $70 \mathrm{~kg}$ dietami zbożowo-rzepakowymi o podobnej koncentracji energii metabolicznej i zbilansowanych pod względem zawartości aminokwasów, ale różniących się zawartością frakcji glukozynolanów. Antyodżywczy wpływ koncentracji glukozynolanów indolowych i alkenowych w paszy określono na podstawie dziennego odłożenia białka w ciele, masy tarczycy, wątroby, ncrck oraz poziomu hormonów tarczycy we krwi.

Dzienne odłożenie białka zmniejszało się o $8,6 \%$, a masa narządów zwiększała się: tarczycy o $210 \%(\mathrm{P}<0,001)$, wątroby o $50 \%(\mathrm{P}<0,01)$, nerck o $17 \%(\mathrm{P}<0,05)$ w miarę wzrostu koncentracji indolowej i alkenowej frakcji GL. Korelacje cząstkowe wskazuja, że glukozynolany indolowe w większym stopniu niż alkenowe wpłynęły na masę narządów, natomiast nie miały wpływu na odłożenie białka. Poziom hormonów tarczycy załcżał od obyđwóch frakcji GL. 